\title{
Testosterone receptor blockade restores cellular immunity in male mice after burn injury
}

\author{
K A N Messingham ${ }^{1,2}$, M Shirazi ${ }^{5}$, L A Duffner ${ }^{1,2}$, \\ M A Emanuele ${ }^{6}$ and E J Kovacs ${ }^{1,2,3,4}$ \\ ${ }^{1}$ Department of Cell Biology, Neurobiology and Anatomy, Loyola University Medical Center, Maywood, Illinois 60153, USA \\ ${ }^{2}$ The Burn and Shock Trauma Institute, Loyola University Medical Center, Maywood, Illinois 60153, USA \\ ${ }^{3}$ Department of Surgery, Loyola University Medical Center, Maywood, Illinois 60153, USA \\ ${ }^{4}$ Immunology and Aging Program, Loyola University Medical Center, Maywood, Illinois 60153, USA \\ ${ }^{5}$ Stritch School of Medicine, Loyola University Medical Center, Maywood, Illinois 60153, USA \\ ${ }^{6}$ Department of Medicine, Loyola University Medical Center, Maywood, Illinois 60153, USA \\ (Requests for offprints should be addressed to E J Kovacs, Department of Cell Biology, Neurobiology and Anatomy, Loyola University Medical Center, \\ Bldg 110, Rm 4220, 2160 South First Avenue, Maywood, Illinois 60153, USA; Email: ekovacs@lumc.edu)
}

\begin{abstract}
Males are known to have increased risk for septic complications after traumatic injury, which appears to be mediated by the inhibitory effects of testosterone on immune function. The role of testosterone in immunity after burn injury, however, remains unclear. Herein, we examined the effects of a testosterone receptor antagonist, flutamide, on delayed type hypersensitivity response $(\mathrm{DTH})$, splenocyte proliferation, interleukin (IL)-2 secretion, and IL-2 receptor (IL-2R) expression in male $\mathrm{BALB} / \mathrm{c}$ mice subjected to a $15 \%$ total body surface area burn or sham injury. Burn- or sham-injured mice were given flutamide s.c. at $30 \mathrm{~min}$ and $24 \mathrm{~h}$ after injury. At $48 \mathrm{~h}$, burn injury caused a $48 \%(P<0 \cdot 001)$ decrease in $\mathrm{DTH}$ response; however, mice that received flutamide treatment did not demonstrate significant suppression of DTH. Likewise, splenocyte proliferation and IL-2
\end{abstract}

production were depressed in burned animals in comparison with sham-injured controls, and flutamide treatment resulted in a partial restoration of these responses. In vitro studies indicated that splenocytes from sham- and burninjured mice were equally sensitive to the suppressive effects of $5 \alpha$-dihydrotestosterone in regard to proliferation and IL-2 production. Further evaluation revealed a decrease in IL-2R expression on splenocytes from burned mice and a partial restoration of this expression with flutamide treatment. Thus blocking testosterone receptor activation improves the cellular immunity in thermally injured mice, possibly through restoration of IL-2 production and IL-2R expression. It remains to be determined whether the effects of testosterone in this injury model are direct or indirect.

Journal of Endocrinology (2001) 169, 299-308

\section{Introduction}

More than 100000 people are admitted to hospital because of burn injury each year in the United States (Smith \& Kraus 1988). For these patients, septic complications are the greatest risk for those who survive the initial injury (Dinkel \& Lebok 1994). The susceptibility to infection, and resultant mortality, is greatly increased after burn, as a result of suppression of cell-mediated immunity (Moss et al. 1988, Dinkel \& Lebok 1994). The immune defects observed after burn include anergy to delayed type hypersensitivity (DTH) antigens (Tchervenkov et al. 1988), decreased activation and proliferation of lymphocytes in response to mitogenic (concanavalin A (Con A)) or antigenic stimulation and decreased cytokine secretion (Wolfe et al. 1982, Teodorczyk-Injeyan et al. 1986, 1987, Moss et al. 1988).
Interleukin-2 (IL-2) is the primary cytokine required for $\mathrm{T}$ lymphocyte activation and proliferation. It has been well established that one of the main factors contributing to decreased $\mathrm{T}$ lymphocyte function, and thus cellular immunity, after burn injury is a dramatic decline in IL-2 production (Wolfe et al. 1982, Wood et al. 1984, Horgan et al. 1994a, b, O'Riordain et al. 1995). Clinically, the ability of peripheral blood mononuclear cells to produce IL-2 in vitro is positively correlated with survival after burn injury (Teodorczyk-Injeyan et al. 1986, Sparkes 1993). In addition to the production and secretion of IL-2, T lymphocyte function is also dependent on expression of functional IL-2 receptor (IL-2R) on the cell surface. The IL-2R is a dimer composed of an inducible, high-affinity $\alpha$-chain (p55) and a constitutive, low-affinity $\beta$-chain (p70/75) (Waldman 1986). Expression of the $\alpha$-chain is increased after antigenic or other stimuli at the initiation of 
an immune response. Thus the p55 IL-2R is a critical regulator of lymphocyte proliferation and resultant cellmediated immunity. There is conflicting evidence regarding the effect of burn injury on the expression of the IL-2R (Teodorczyk-Injeyan et al. 1987, Horgan et al. 1994a, O’Riordain et al. 1995, Meert et al. 1996). However, in studies in which the IL-2R was decreased after burn, inability to recover receptor expression was correlated with mortality after injury (Teodorczyk-Injeyan et al. 1986, Sparkes 1993).

Nearly $80 \%$ of patients admitted for burn or other traumatic injury are male (Offner et al. 1999). Clinically, males are at increased risk for suffering morbidity and mortality from sepsis after burn than females (Schroder et al. 1998, Offner et al. 1999). A variety of experimental trauma models also reveal a sex difference in immunity and survival after injury, and suggest that testosterone mediates some of the immune suppression observed in males (Wichmann et al. 1996, 1997, Angele et al. 1997, 1998). In these studies either chemical (androgen receptor blockade) or surgical (gonadectomy) castration protected mice from the decreased lymphocyte proliferation and cytokine secretion and increased mortality after sepsis, which are normally observed in intact male mice. The mechanism by which testosterone mediates this suppression of immunity remains to be determined. In addition, the role of testosterone in immune suppression after burn trauma has not previously been explored.

Our current studies aim to determine whether the presence of testosterone influences the suppression of cellular immunity in male mice after burn injury, and to examine the role of testosterone in the regulation of cellular immunity as determined by the DTH and splenocyte proliferative responses, IL-2 production and IL-2R expression by splenic lymphocytes isolated from burn-injured mice.

\section{Materials and Methods}

\section{Induction of thermal injury}

Male BALB/c mice 10 weeks of age (Charles River Laboratories, Portage, MI, USA) were subjected to dorsal scald injury as previously described (Gregory et al. 2000a). Briefly, mice were anesthetized $(40 \mathrm{mg} / \mathrm{kg}$ sodium pentobarbital in $0.9 \%$ normal saline, i.p.; Nembutal, Abbott Laboratories, Abbott Park, IL, USA), and shaved with animal clippers to expose their dorsal surface. Animals were then placed into a plastic template designed to expose $15 \%$ of their total body surface area. The mouse and template were then immersed into a water bath at room temperature (sham), or at $100{ }^{\circ} \mathrm{C}$ (burn), for $8 \mathrm{~s}$. All animals were thoroughly dried with a towel to prevent further scalding and received intraperitoneal (i.p.) resuscitation with $1.5 \mathrm{ml} \mathrm{0.9 \%}$ normal saline. They were then placed under warming lamps until recovery from anesthesia, after which they were returned to their cages. To avoid complications arising from daily cortisol fluctuations, all procedures were performed between 0830 and $1030 \mathrm{~h}$, when circulating cortisol is at its lowest. All animal studies described herein were performed in strict accordance with the guidelines set forth by the Loyola University Chicago Institutional Animal Care and Use Committee.

\section{Flutamide treatment}

The effects of testosterone were inhibited by means of the administration of flutamide, a non-steroidal androgen receptor antagonist (Kemppainen et al. 1992), dissolved in sesame oil. Both sham- and burn-injured mice were treated with oil vehicle or flutamide $(25 \mathrm{mg} / \mathrm{kg}$, s.c. $)$ at $30 \mathrm{~min}$ and $24 \mathrm{~h}$ after the burn (Wichmann et al. 1997).

\section{Circulating testosterone}

At the time the animal was killed, whole blood was collected via cardiac puncture and allowed to clot at room temperature for $2 \mathrm{~h}$. The blood was centrifuged and the serum was collected, aliquoted and stored at $-80{ }^{\circ} \mathrm{C}$ until required for analysis. Total testosterone of duplicate samples was determined using a commercially available radioimmunoassay kit (DSL-4900, Diagnostic Systems Laboratories, Inc.Webster, TX, USA).

\section{Determination of DTH responses}

DTH responses were induced as described previously (Hansbrough et al. 1984, Faunce et al. 1997, Gregory et al. $2000 a$ ). Briefly, 5 days before thermal injury all groups of experimental mice were sensitized to the hapten 2,4-dinitrofluorobenzene (DNFB) (Acros Organics, New Jersey, NJ, USA) by the application of $20 \mu \mathrm{l}$ of a $0.5 \%$ solution in acetone:olive oil (4:1) directly to the shaved skin of the abdomen. Twenty-four hours after thermal injury, ear thickness measurements were made with a micrometer and then an eliciting dose $(20 \mu \mathrm{l} 0 \cdot 2 \%$ DNFB) was applied to the pinna of the right ear. At $24 \mathrm{~h}$ after elicitation ( $48 \mathrm{~h}$ after the burn), both the unelicited and the elicited ear were measured by an observer blinded to the study group. The magnitude of ear swelling was expressed as \% change in ear thickness using the following formula: (change in thickness/pre-elicitation thickness) $\times$ $100 \%$, where change in thickness = post-elicitation - preelicitation ear thickness. Measurements on the left (completely unmanipulated) ear were obtained and served as internal controls for each animal. A group of naive animals were not subjected to either sham or burn injury and received only the elicitation dose of DNFB, to allow for the determination of non-specific ear swelling caused by application of the hapten in oil. The naive mice routinely showed a 3-9\% increase in ear thickness in response to the 
eliciting dose of DNFB; furthermore, splenocyte proliferation and cytokine secretion of naive mice were not different from those in sham-injured, oil control-treated mice (data not shown).

\section{Analysis of splenocyte proliferation}

At the time of killing, spleens were aseptically removed and single cell suspensions of splenocytes were plated into 96-well microtiter plates at a density of 250000 cells per well in RPMI 1640 (Gibco BRL, Grand Island, NY, USA) supplemented with L-glutamine $(2 \mathrm{mM})$, penicillin-G $(100 \mathrm{U} / \mathrm{ml})$, streptomycin $(100 \mu \mathrm{g} / \mathrm{ml})$, and $10 \%$ fetal bovine serum. The viability of the cells was confirmed to be $>94 \%$ by trypan blue exclusion. Triplicate splenocyte cultures were incubated for $72 \mathrm{~h}$ at $37^{\circ} \mathrm{C}, 5 \%$ $\mathrm{CO}_{2}$ in the presence or absence of concanavalin A (Con A; $2 \mu \mathrm{g} / \mathrm{ml})$. A colorimetric assay (3-(4, 5-dimethylthiazol-2yl)-2, 5-diphenyltetrazolium bromide (MTT); Sigma Chemical Co., St Louis, MO, USA) was utilized to measure proliferation as described previously (Gregory et al. 2000a). Briefly, after $68 \mathrm{~h}$ of incubation, plates were centrifuged, the supernatant was removed, and $50 \mu \mathrm{l}$ of a $1 \mathrm{mg} / \mathrm{ml}$ solution of MTT in phenol red-free RPMI 1640 was added to each well. Plates were then incubated for the remaining $4 \mathrm{~h}$ at $37^{\circ} \mathrm{C}, 5 \% \mathrm{CO}_{2}$. After the incubation and after centrifugation, the untransformed MTT was removed by careful inversion and blotting. Next, $50 \mu \mathrm{l}$ isopropanol was added and the optical density of each well was measured using an automatic microplate reader at a wavelength of $540 \mathrm{~nm}$. The adjusted mean absorbance for each animal was determined by averaging values obtained from triplicate wells containing medium alone or Con A for each animal and then subtracting the unstimulated absorbance (medium alone) value from the Con Astimulated absorbance. The adjusted means were then averaged to obtain an overall mean absorbance \pm s.E.M. for each experimental group.

\section{Evaluation of splenocyte IL-2 production}

Splenocyte cultures were set up in a manner identical to that of the proliferation assay. After a 20-h incubation $\left(37^{\circ} \mathrm{C}, 5 \% \mathrm{CO}_{2}\right)$, the plates were centrifuged and triplicate supernatants were pooled, aliquoted, and frozen at $-80{ }^{\circ} \mathrm{C}$ prior to cytokine determination. IL-2 secretion was determined by ELISA using a commercially available sandwich ELISA kit using paired capture and detection antibodies and standard specific for murine IL-2 (Endogen Inc., Cambridge, MA, USA). The minimum level of detection of this assay was $15 \mathrm{pg} / \mathrm{ml}$.

\section{Evaluation of cell-surface antigen expression}

Splenocyte cell populations were analyzed via direct immunofluorescence to determine the percentage of
Table 1 Circulating testosterone concentrations. Data are expressed as mean testosterone concentration in $\mathrm{ng} / \mathrm{ml} \pm$ S.E.M. $(n=3-5$ per group $)$

\begin{tabular}{ll} 
& $\begin{array}{c}\text { Testosterone } \\
(\mathrm{ng} / \mathrm{ml})\end{array}$ \\
\cline { 2 - 2 } & \\
$\begin{array}{l}\text { Treatment group } \\
\text { Sham injury } \\
\text { Oil vehicle }\end{array}$ & $15 \cdot 4 \pm 1 \cdot 2^{*}$ \\
Flutamide & $1 \cdot 42 \pm 0 \cdot 9$ \\
Burn injury & \\
Oil vehicle & \\
Flutamide & $0 \cdot 6 \pm 0.5$ \\
& $4 \cdot 0 \pm 3 \cdot 7$
\end{tabular}

Mice were given a 15\% total body surface area sham or burn injury and whole blood was obtained from them $48 \mathrm{~h}$ after injury, via cardiac puncture. Serum was evaluated for the presence of unbound testosterone by RIA. ${ }^{*} P<0.05$ compared with all other groups (ANOVA and Fisher's least significant difference post-hoc analysis).

macrophages (Mac-3), T cells (CD4 or CD8a), B cells (CD45/B220) and IL-2R (p55/CD25) receptor expression, using flow cytometry (Pharmingen, San Diego, CA, USA). After blocking for $30 \mathrm{~min}\left(\mathrm{PBS} / 2 \% \mathrm{BSA}, 4^{\circ} \mathrm{C}\right.$ ), $1 \cdot 0 \times 10^{6}$ splenocytes were incubated for $30 \mathrm{~min}$ with $0.5 \mu \mathrm{g}$ antigen-specific or isotype control antibody on ice in the dark. Cells were then washed twice (PBS $/ 2 \%$ BSA, $4{ }^{\circ} \mathrm{C}$ ) and fixed in $2 \%$ paraformaldehyde (Sigma Chemical). All flow cytometry was performed using a Becton-Dickinson FACSCalibur and Cell Quest software. Data are expressed as mean percent positively staining cells \pm s.E.M. of 10000 events.

\section{Statistical analysis}

Data are expressed as mean \pm S.E.M. of each group unless otherwise indicated. Analysis of variance (ANOVA) was performed using a statistical analysis package (GB-STAT, Dynamic Microsystems) to assess differences among all experimental groups. If ANOVA indicated a significant main or interactive effect, Fisher's protected least significant difference was used to make post-hoc comparisons. $P<0 \cdot 05$ was considered to be significant.

\section{Results}

\section{Circulating testosterone concentrations}

Burn and other traumatic injuries have been shown to decrease circulating testosterone concentrations in males (Lephart et al. 1987). To evaluate whether our burn injury altered testosterone concentrations, and if flutamide treatment had any effect on these values, circulating total testosterone was measured by RIA. As shown in Table 1, sham-injured mice treated with oil vehicle had normal circulating concentrations of testosterone, and flutamide 


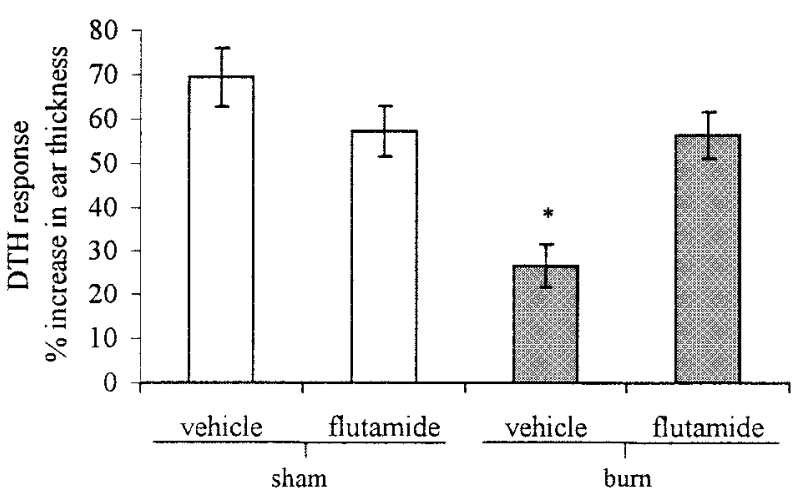

Figure 1 DTH response in sham- and burn-injured mice treated with oil vehicle or flutamide $(25 \mathrm{mg} / \mathrm{kg}$, s.c.) $30 \mathrm{~min}$ and $24 \mathrm{~h}$ after the burn. Mice were killed $48 \mathrm{~h}$ after burn and DTH response was evaluated as an in vivo measure of cell-mediated immunity. Data are shown as the mean $\%$ change in ear thickness \pm S.E.M. $(n=9-11$ mice per group). ${ }^{*} P<0 \cdot 001$ compared with all other groups.

treatment of sham-injured mice resulted in a significant $(P<0 \cdot 01)$ decrease in testosterone concentration in the circulation. As expected, burn injury (oil vechile) resulted in a significant $(P<0 \cdot 01)$ decrease in testosterone concentration, but flutamide treatment of burned mice did not further reduce hormone concentrations in this group.

\section{DTH response}

The DTH response was used as an in vivo measure of cellular immunity. Mice were sensitized 5 days before injury to ensure that antigen exposure occurred when the animals were immunologically intact. Twenty-four hours after sham or burn injury, DTH responses were elicited via a second application of antigen to the pinna of each mouse's right ear. The percentage change in ear thickness is proportional to the immunological competence of the mouse. As shown in Fig. 1, treatment of sham-injured mice with oil resulted in a robust increase in ear thickness. Administration of flutamide had no affect on sham-injured animals in comparison with sham-injured mice given an oil injection. Burn injury (plus oil vehicle) resulted in a dramatic decrease $(P<0 \cdot 001)$ in the amount of ear swelling in comparison with that in both groups of sham-injured mice. Flutamide treatment of burned mice resulted in a complete restoration of the DTH response to the levels observed in sham-injured mice (treated with oil vehicle or flutamide).

\section{Splenocyte proliferation}

Previous studies have shown that, coincident with the suppression of DTH responses, splenocyte proliferation was decreased in male BALB/c mice at 2 and 4 days after burn injury (Gregory et al. 2000a). To evaluate the role of testosterone in the control of cellular immunity after burn,

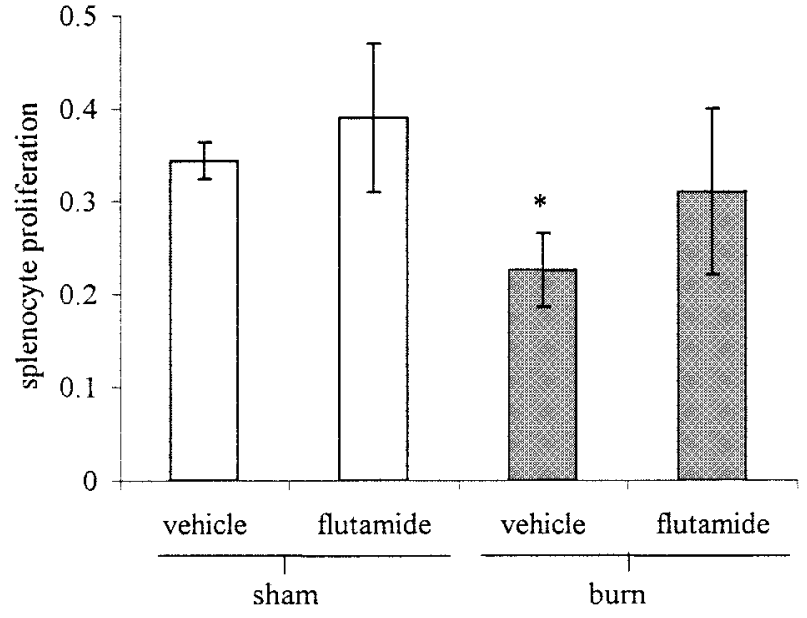

Figure 2 Total splenocyte proliferation in sham- and burn-injured mice treated with oil vehicle or flutamide $(25 \mathrm{mg} / \mathrm{kg}$, s.c. $) 30 \mathrm{~min}$ and $24 \mathrm{~h}$ after the burn. Mice were killed $48 \mathrm{~h}$ after burn and splenocytes were cultured in the presence of medium alone or Con A $(2 \mu \mathrm{g} / \mathrm{ml})$ for $72 \mathrm{~h}$. The MTT assay was used to assess proliferation. The data are expressed as mean absorbance at $540 \mathrm{~nm}$ (Con A - medium) \pm S.E.M. from one experiment $(n=4-6$ mice per group). ${ }^{*} P<0 \cdot 05$ compared with sham-injured mice treated with oil or flutamide.

splenic lymphocyte proliferative responses were evaluated in response to the $\mathrm{T}$ cell mitogen, Con $\mathrm{A}$, as shown in Fig. 2. In agreement with the findings of the DTH assay, sham-injured mice treated with oil or flutamide demonstrated similar proliferative capacity after culture with Con A. Burn injury (and oil vehicle) resulted in a significant suppression of mitogen-induced proliferation $(P<0 \cdot 05)$. Mice treated with flutamide after burn demonstrated a partial restoration of lymphocyte proliferation, although this recovery was not as marked as was seen with the DTH response.

\section{Splenocyte production of IL-2}

It has been well established that burn injury results in decreased IL-2 production, which contributes to the observed failure of $\mathrm{T}$ lymphocyte proliferation observed in both clinical and experimental burn models of injury (Wood et al. 1984, O'Riordain et al. 1993). To evaluate the role of testosterone in the regulation of IL-2 production, and to examine the possibility that administration of flutamide restores cellular immunity by increasing production of this cytokine, IL-2 secretion by cultured splenocytes was determined. As shown in Fig. 3, there was no difference in IL-2 production by splenocytes isolated from sham-injured mice treated with oil vehicle $(1120 \pm 120 \mathrm{pg} / \mathrm{ml})$ or flutamide $(1082 \pm 189 \mathrm{pg} / \mathrm{ml})$. As expected, burn injury resulted in a significant decrease $(P<0 \cdot 05)$ in splenic production of IL-2 $(741 \pm 123 \mathrm{pg} / \mathrm{ml})$ in comparison with that in sham-injured mice. Flutamide 


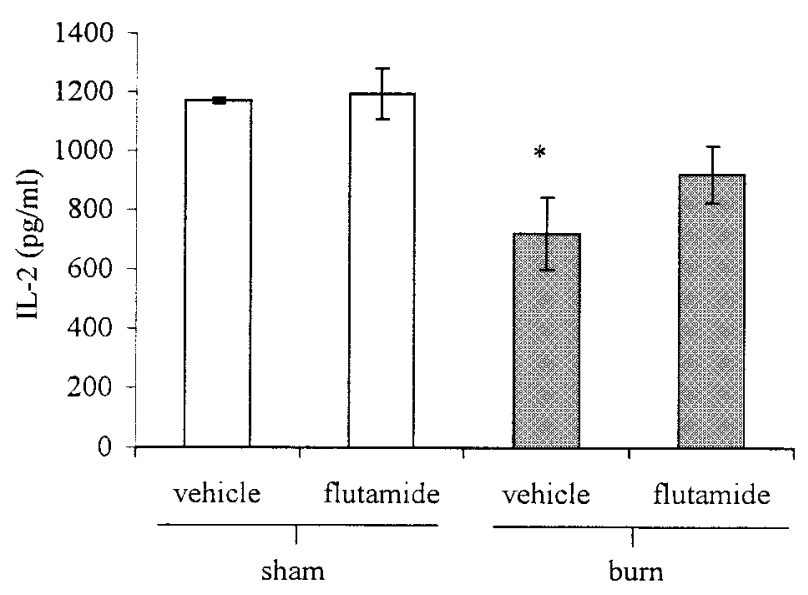

Figure 3 IL-2 production by total splenocytes isolated from shamand burn-injured mice treated with oil vehicle or flutamide ( $25 \mathrm{mg} / \mathrm{kg}$, s.c.) $30 \mathrm{~min}$ and $24 \mathrm{~h}$ after the burn. Mice were killed $48 \mathrm{~h}$ after burn and splenocytes were cultured in the presence of medium alone or Con A ( $2 \mathrm{ug} / \mathrm{ml})$ for $20 \mathrm{~h}$. IL-2 was measured in the culture supernatants by ELISA. Unstimulated cells (medium alone) did not produce any detectable IL-2. Data are expressed as mean concentration of IL- $2 \pm$ S.E.M. for each group $(n=6-8$ mice per group). ${ }^{*} P<0 \cdot 05$ compared with sham-injured mice treated with oil or flutamide.

treatment only partially restored splenocyte secretion of IL-2 $(923 \pm 94.5 \mathrm{pg} / \mathrm{ml})$ by lymphocytes isolated from burned animals, which was similar to the findings in the proliferation assay.

\section{Characterization of splenocyte subpopulations}

The splenocyte suspensions evaluated for their proliferative responses to mitogen were unfractionated, thus they included primarily $\mathrm{T}$ and $\mathrm{B}$ lymphocytes and macrophages. The proportion of each cell type present in the cultures could influence not only the mitogen-induced proliferation and IL-2 production in vitro, but also the in vivo DTH response, as this assay depends on systemic lymphocyte recruitment and proliferation. To explore the possibility that a change in cell number or proportion, rather than function, was affecting these assays, the percentage and total number per spleen of macrophages $\left(\mathrm{Mac}^{-} 3^{+}\right), \mathrm{T}$ cells $\left(\mathrm{CD}^{+}\right.$or $\left.\mathrm{CD} 8^{+}\right)$and B cells (CD45R/ $\mathrm{B} 220^{+}$), were analyzed using direct immunofluorescence and flow cytometry. As shown in Table 2, there were no significant differences in the percentages of $\mathrm{CD}^{+} \mathrm{T}$, $\mathrm{CD}^{+} \mathrm{T}$ or $\mathrm{B}$ cells with regard to the various treatment groups. Both groups of burned mice showed an increase in the percentage of splenic macrophages $\left(\mathrm{Mac}^{-} 3^{+}\right)$, in comparison with sham mice. This finding was statistically significant $(P<0.05)$ in the group of mice treated with oil vehicle after burn, but not in those treated with flutamide. When the absolute number of each cell population was determined, burn injury resulted in a significant $(P<0 \cdot 05)$ reduction in the number of CD4-, CD8- and B220expressing cells. There was no reduction, however, in the number of $\mathrm{Mac}^{+}$cells, which resulted in an increased percentage of this cell type in comparison with others.

\section{The effects of in vitro testosterone on proliferation}

The mechanism by which testosterone mediates its immune suppressive effects after traumatic injury is unknown. Although flutamide treatment does not alter testosterone concentrations in this model (Table 1), it is possible that burn injury could alter hormone receptor expression or cell signaling pathways, resulting

Table 2 Immunofluorescent staining of splenocyte subpopulations and IL-2 receptor. All values are represented as percent (number) of positively immunostained cells minus positively stained isotype control cells \pm S.E.M. ( $n=4-6$ animals per group)

Immunopositive cells $\left(\%\left(\right.\right.$ absolute number $\left.\left.\times 10^{6}\right)\right)$

\begin{tabular}{lllll}
\hline $\mathrm{CD}^{+}$ & $\mathrm{CD}^{+}$ & $\mathrm{B} 220^{+}$ & $\mathrm{Mac}^{+} 3^{+}$ & $\mathrm{IL}-2 \mathrm{R}$ \\
\hline
\end{tabular}

\section{Treatment}

Sham injury

Oil vehicle

Flutamide

$$
\begin{gathered}
16 \cdot 8 \pm 2 \cdot 7 \\
(20 \cdot 0 \pm 3 \cdot 2) \\
14 \cdot 6 \pm 3 \cdot 2 \\
(17 \cdot 5 \pm 1 \cdot 9)
\end{gathered}
$$

Burn injury

Oil vehicle

$$
\begin{aligned}
& 16 \cdot 8 \pm 0 \cdot 1 \\
& (3 \cdot 3 \pm 0 \cdot 1)^{*}
\end{aligned}
$$

Flutamide

$$
\begin{gathered}
7 \cdot 9 \pm 0 \cdot 3 \\
(9 \cdot 8 \pm 0 \cdot 6) \\
11 \cdot 1 \pm 1 \cdot 6 \\
(13 \cdot 3 \pm 2 \cdot 4)
\end{gathered}
$$

$$
\begin{gathered}
8 \cdot 7 \pm 2 \cdot 5 \\
(6 \cdot 9 \pm 1 \cdot 9) \dagger \\
9 \cdot 7 \pm 0 \cdot 7 \\
(8 \cdot 2 \pm 0 \cdot 5)^{*}
\end{gathered}
$$

$$
\begin{gathered}
54 \cdot 7 \pm 1 \cdot 1 \\
(68 \cdot 4 \pm 2 \cdot 6) \\
54 \cdot 1 \pm 6 \cdot 6 \\
(64 \cdot 8 \pm 8 \cdot 9) \\
\\
52 \cdot 3 \pm 3 \cdot 5 \\
(41 \cdot 5 \pm 2 \cdot 4)^{*} \\
53 \cdot 7 \pm 3 \cdot 5 \\
(45 \cdot 6 \pm 2 \cdot 9)^{\star}
\end{gathered}
$$

$14 \cdot 3 \pm 2 \cdot 9$

$(17 \cdot 8 \pm 4 \cdot 3)$

$15 \cdot 3 \pm 6 \cdot 2$

$(18 \cdot 4 \pm 8 \cdot 1)$
$23 \cdot 1 \pm 0 \cdot 4$ *
$(18 \cdot 3 \pm 0 \cdot 3)$
$21 \cdot 5 \pm 1 \cdot 4$
$(18 \cdot 3 \pm 1 \cdot 2)$

$63 \cdot 9 \pm 2 \cdot 6$

$(79 \cdot 8 \pm 4 \cdot 3)$

$62 \cdot 6 \pm 3 \cdot 5$

$(75 \cdot 1 \pm 5 \cdot 8)$

$53 \cdot 6 \pm 1 \cdot 3 \dagger$

$(47.5 \pm 0.9)^{*}$

$60 \cdot 4 \pm 2 \cdot 7$

$(51 \cdot 3 \pm 2 \cdot 4)^{*}$

Mice were given a $15 \%$ total body surface area sham or burn injury and splenocytes were obtained from them $48 \mathrm{~h}$ after injury and evaluated for expression of surface antigens (CD4, CD8, B220 and Mac-3). To evaluate IL-2R (p55/CD25), cells were cultured overnight in the presence of $2 \mu \mathrm{g} / \mathrm{ml}$ Con A then washed and stained for receptor expression. ${ }^{*} P<0.05$ compared with sham-injured mice; $† P<0.05$ compared with all other groups (ANOVA and Fisher's least significant difference post-hoc analysis). 


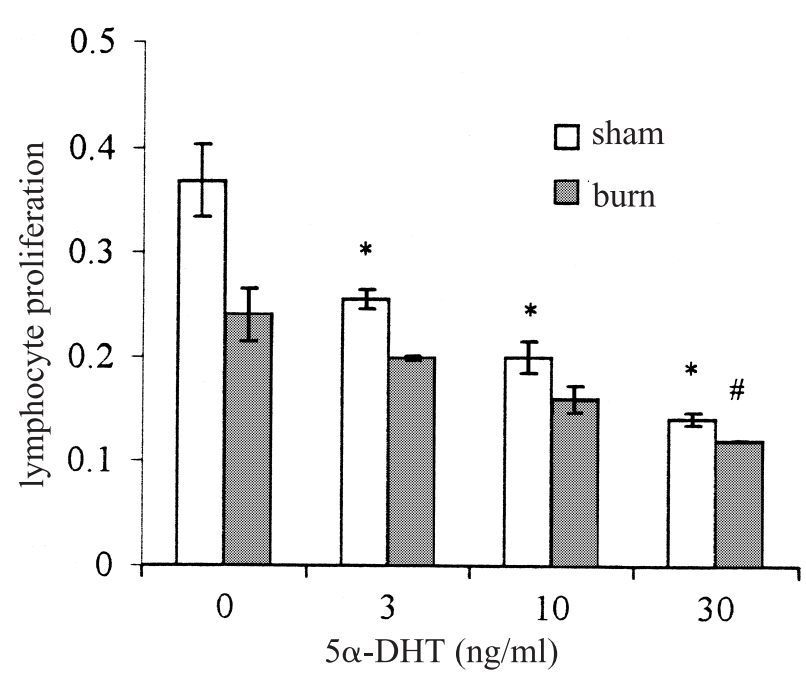

Figure 4 Non-adherent splenocyte (lymphocyte) proliferation from sham- and burn-injured animals in response to in vitro exposure to Con A $(2 \mu \mathrm{g} / \mathrm{ml})$ alone or Con A plus 3, 10 or $30 \mathrm{ng} / \mathrm{ml} 5 \alpha-$ dihydrotestosterone (DHT). Mice were killed $48 \mathrm{~h}$ after the burn and splenocytes were adherence-purified and cultured for $72 \mathrm{~h}$. The MTT assay was used as an indicator of proliferation. The data are expressed as mean absorbance at $540 \mathrm{~nm}$ (Con A medium) \pm S.D. of triplicate cultures from one experiment. ${ }^{*} P<0 \cdot 05$ compared with lymphocytes from sham-injured mice treated with $0 \mathrm{ng} / \mathrm{ml} \mathrm{DHT} ; \# P<0.05$ compared with lymphocytes isolated from burn-injured mice and cultured with $0 \mathrm{ng} / \mathrm{ml}$ DHT.

in a differential susceptibility to the effects of testosterone in burned animals. To examine this possibility, nonadherent splenocytes (lymphocytes) from sham- and burninjured mice were cultured with increasing concentrations $(0,3,10$ and $30 \mathrm{ng} / \mathrm{ml})$ of a non-aromatizable form of testosterone, $5 \alpha$-dihydrotestosterone (DHT), and proliferation was evaluated using the MTT assay. As shown previously (Fig. 2), the lymphocytes from burned mice demonstrated significantly $(P<0 \cdot 05)$ decreased $(34 \cdot 8 \%)$ proliferation in response to Con A (0 ng/ml DHT) compared with those from sham-injured mice (Fig. 4). Lymphocytes from sham and burn mice also revealed a dose-dependent decrease in proliferation in response to in vitro DHT. Addition of 3, 10 or $30 \mathrm{ng} / \mathrm{ml}$ DHT resulted in a $30 \cdot 8 \%, 45 \cdot 1 \%$ and $62 \cdot 1 \%$ decrease in proliferation lymphocytes isolated from sham-injured mice and a $17 \cdot 1 \%, 33 \cdot 5 \%$ and $50 \cdot 2 \%$ decrease in proliferation of lymphocytes isolated from burn injured mice respectively.

\section{The effects of in vitro testosterone on IL-2 production}

Because differences in testosterone sensitivity could also affect cellular immunity by influencing cytokine production, the effect of increasing concentrations $(0,3,10$ and $30 \mathrm{ng} / \mathrm{ml}$ ) of DHT on splenocyte IL-2 production was evaluated. In agreement with the splenocyte proliferation data shown in Fig. 4, the secretion of IL-2, in the absence

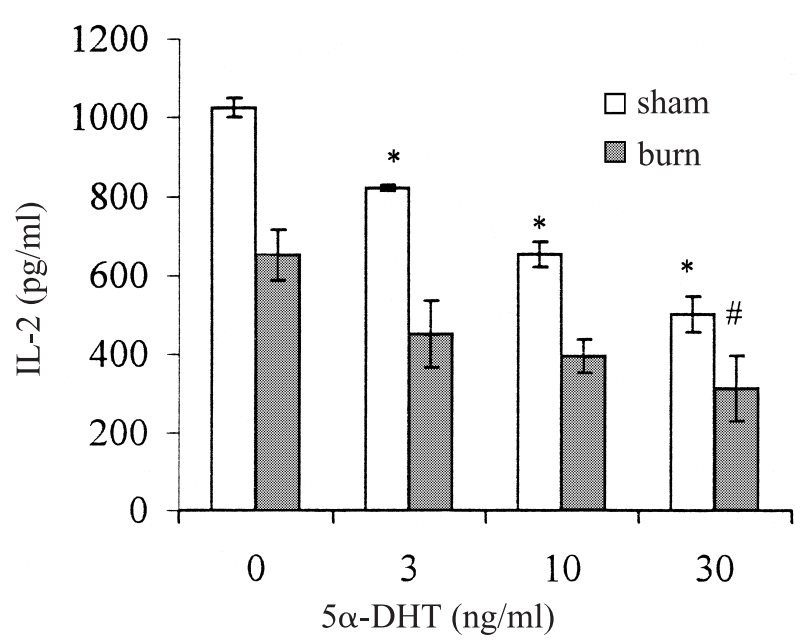

Figure 5 IL-2 production by non-adherent splenocytes (lymphocytes) adherence-purified from sham- and burn-injured animals in response to in vitro exposure to Con A $(2 \mu \mathrm{g} / \mathrm{ml})$ alone or Con A plus 3, 10 or $30 \mathrm{ng} / \mathrm{ml} 5 \alpha$-dihydrotestosterone (DHT). Mice were killed $48 \mathrm{~h}$ after the burn, splenocytes were cultured for $20 \mathrm{~h}$, and the supernatant IL-2 was determined by ELISA.

${ }^{*} P<0.05$ compared with lymphocytes isolated from sham-injured mice treated and cultured with $0 \mathrm{ng} / \mathrm{ml} \mathrm{DHT} ; \# P<0.05$ compared with lymphocytes isolated from burn-injured mice and incubated with $0 \mathrm{ng} / \mathrm{ml}$ DHT.

of DHT, was suppressed by $36.4 \%$ in burned mice in comparison with that in sham-injured mice (Fig. 5). IL-2 production was further suppressed by the addition of increasing doses of DHT: addition of 3, 10 or $30 \mathrm{ng} / \mathrm{ml}$ DHT resulted in a $19 \cdot 8 \%, 36 \cdot 2 \%$, and $51 \cdot 0 \%$ decrease in proliferation of lymphocytes isolated from sham-injured mice and a $30 \cdot 8 \%, 39 \cdot 5 \%$ and $51 \cdot 8 \%$ decrease in proliferation of lymphocytes isolated from burn-injured mice respectively.

\section{IL-2 receptor expression}

In addition to IL-2 production, the level of IL-2R ( $\mathrm{p} 55 / \mathrm{CD} 25)$ expression is critical for a productive cellular immune response. Therefore, the p55/CD25 receptor levels were measured on mitogen-stimulated $(2 \mu \mathrm{g} / \mathrm{ml}$ Con A, $18 \mathrm{~h}$ ) splenocytes from sham and burn mice treated with oil or flutamide. IL-2R was not detectable on freshly isolated cells from any experimental group of mice. Flutamide treatment did not affect IL-2R expression in sham-treated mice (Table 2). Burned mice treated with oil vehicle demonstrated a decrease in the percent IL-2R ${ }^{+}$ splenocytes in comparison with sham-injured mice treated with oil $(53 \cdot 6 \pm 1 \cdot 3$ compared with $63.9 \pm 2 \cdot 6)$, which was restored by treatment with flutamide after burn injury $(60 \cdot 4 \pm 2 \cdot 7)$. Interestingly, when absolute cell numbers expressing IL-2R were examined, burn injury (oil treatment) resulted in a decrease $(79 \cdot 8 \pm 4 \cdot 3$ sham compared 
with $47.5 \pm 0.9$ burn) in the number of IL-2R expressing cells; this was not fully restored by flutamide treatment (51.3 $\pm 2 \cdot 4$ in the burn-injured, flutamide-treated group).

\section{Discussion}

Males are at a significantly increased risk for developing septic complications after burn or other traumatic injury (Offner et al. 1999), and suffer from increased mortality in comparison with females that are matched for age, type and severity of injury (Schroder et al. 1998). These findings suggest that immunity after injury is influenced by the gonadal hormones, estrogen and testosterone. In support of this, injured male mice have decreased proliferation of lymphocytes and secretion of cytokines (including IL-2) that are associated with increased susceptibility to sepsis, in comparison with females (Wichmann et al. 1996). In addition, castration of males before injury, or flutamide treatment after injury, restores immune responses, and improves survival after septic challenge (Wichmann et al. 1996, 1997, Angele et al. 1997). Likewise, treatment of female mice with DHT before injury results in defects in immunity that are similar to those seen in intact injured males (Angele et al. 1998). Thus it is likely that the increased morbidity and mortality observed in males after traumatic injury are due to the presence of the immune-suppressive androgenic hormone, testosterone. The current studies confirm this hypothesis and extend the previous experimental findings in traumatic injury models to include burn injury.

The suppressive effects of testosterone on immune function are widely accepted; however, the mechanism for this androgen control of immunity is not well understood. Both in vivo and in vitro testosterone exposure results in decreases in $\mathrm{B}$ and $\mathrm{T}$ lymphocyte expansion in the bone marrow, spleen, and thymus (Weinstein \& Berkovich 1981, Olsen et al. 1994, Olsen \& Kovacs 1996, Viselli et al. 1997). Burn injury is also known to alter splenocyte subpopulations within these organs (Kupper et al. 1985, O'Mahony et al. 1985), which could influence the DTH and splenocyte proliferative responses. In the current studies, evaluation of the absolute number of each cell type revealed a decrease in $\mathrm{T}$ and $\mathrm{B}$ cells, but no change in splenic macrophages, thereby resulting in an increase in the overall percentage of macrophages (Table 2). Flutamide treatment did not affect these observations, further suggesting that androgen receptor blockade after burn is altering the function of immune cells resulting in restoration of the DTH response in vivo.

The macrophage is known to have a key role in mediating injury-induced immune suppression via the production of factors such as prostaglandin $\mathrm{E}_{2}\left(\mathrm{PGE}_{2}\right)$, transforming growth factor (TGF) $\beta$ and IL-6 (MillerGraziano et al. 1993, Olsen et al. 1994, Gregory et al. 2000b). The production of these factors after burn is associated with decreased lymphocyte functions including proliferation, IL-2 production and IL-2R expression (Miller-Graziano et al. 1991, 1993, Fukushima et al. 1994, Horgan et al. 1994a, Meert et al. 1996, Gregory et al. $2000 c$ c). Furthermore, exposure of macrophages to testosterone can increase production of TGF- $\beta$ directly (Benten et al. 1999), and thus that of IL-6 and PGE 2 (MillerGraziano et al. 1991, 1993, Olsen et al. 1994). Therefore, an increase in the percentage of macrophages after injury would result in an exaggerated effect of these factors on lymphocyte function, which could be ameliorated by the administration of flutamide.

Both burn and other traumatic injury alter circulating concentrations of gonadal steroid hormones. Specifically, estrogen concentrations are enhanced in both males and females, whereas testosterone is decreased in males (Woolf et al. 1985, Lephart et al. 1987, Christeff et al. 1992, Fourrier et al. 1994, Sharma et al. 1996). Despite the finding that injury decreases the immune-suppressive androgenic hormones, flutamide treatment consistently results in restoration of cellular immune function after trauma (Wichmann et al. 1996, 1997, Angele et al. 1997). The current studies also demonstrate a decrease in circulating testosterone after burn injury, which was further reduced in sham-injured mice, but not in burn-injured mice, by flutamide treatment. In vivo flutamide treatment has variable effects on testosterone concentrations in noninjury models (Falsetti et al. 1999, Zaccheo et al. 1999, Chertin et al. 2000); however, injury models utilizing a hemorrhagic shock reveal a further decrease in serum testosterone after flutamide treatment in both control and hemorrhaged mice (Samy et al. 2000). In the current study, the lack of any affect of flutamide on testosterone concentrations in burned mice is likely to be the result of the very low concentrations of testosterone in the burned animals.

The suppressive nature of testosterone after injury, in the presence of decreased circulating concentrations of the hormone, is admittedly counterintuitive. Whereas increased glucocorticoids after injury are believed to regulate the decrease in testosterone after injury (Lephart et al. 1987), glucocorticoid concentrations are not affected by flutamide treatment (Wichmann et al. 1997). Thus the beneficial effects of flutamide treatment on immunity after injury are not the result of decreased circulating corticosterone. It has been suggested that even a small concentration of testosterone is enough to produce immune depression in an immunologically compromised host (Angele et al. 1997). It is also possible that burn injury results in increased androgen receptor expression, which would allow for the increased influence of low circulating testosterone concentrations.

The current studies reveal that in vivo testosterone blockade completely restores the DTH response, but only partially restores lymphocyte proliferation and IL-2 production. In addition, in vivo flutamide treatment 
modulated immunity only in burned mice, whereas in vitro testosterone had approximately equal suppressive effects on splenocytes of burn- and sham-injured animals (proliferation and IL-2 secretion). Taken together, these findings suggest that flutamide may have testosteroneindependent affects on splenocytes. In fact, androgen depletion by castration or flutamide treatment has been shown to increase estrogen receptor expression in a variety of cells, including T cells (West et al. 1990, Bodker et al. 1994, Kruithof-Dekker et al. 1996, Samy et al. 2000). Furthermore, preliminary studies suggest that, not only are estrogen concentrations increased after burn as previously reported (Woolf et al. 1985, Lephart et al. 1987), but flutamide treatment further augments this increase (K A N Messingham, M A Emanuele and E J Kovacs, unpublished observation). Such flutamide-induced increases in estrogen receptor expression would have little function in vitro (in the absence of estrogen); however, increased estrogen receptor expression on lymphocytes, in combination with increased circulating estradiol after burn injury, would probably stimulate lymphocyte functions in vivo.

There are conflicting reports regarding the effects of injury on IL-2R expression (Teodorczyk-injeyan et al. 1986, 1989, Horgan et al. 1994b, O’Riordain et al. 1995). It is unknown whether the small decrease in IL-2R expression after burn, and its restoration by flutamide, is biologically relevant (Table 2). It is possible that a small restoration of receptor expression, in combination with a partial restoration of IL-2 production, could provide a mechanism for the recovery of splenocyte proliferation in flutamide-treated mice. However, as the IL-2R expression was fully recovered, but proliferation and IL-2 production were only partially restored, it is unlikely that this change in IL-2R expression is relevant. In addition, in experiments demonstrating reduced IL-2R after injury, lymphocyte proliferation could be restored by the addition of exogenous IL-2 (Teodorczyk-Injeyan et al. 1986, Sparkes 1993, Horgan et al. 1994b). Thus it appears that the lack of IL-2, not IL-2R, is the critical defect in lymphocyte function after burn.

The current studies are the first to demonstrate that blocking testosterone in male mice after burn injury results in recovery of immunity. The involvement of gonadal steroids in the morbidity and mortality after burn injury suggests that sex-specific injury therapies may be necessary. In support of this, studies by Gregory et al. (2000a) found that estrogen concentrations in females reach immune-suppressive pregnancy levels, whereas hormone concentrations in males are similar to those found in cycling females (immune stimulatory). Furthermore, ovariectomy of female mice resulted in restoration of immunity after burn. Recently, the administration of estrogen to male mice was shown to improve immunity after injury (Knoferl et al. 2000). Thus, in males, administration of low (stimulatory) concentrations of estrogen could prove to be beneficial to lymphocyte functions whereas, in females, administration of testosterone, or blocking of estrogen, may result in improved immunity and decreased susceptibility to sepsis after burn injury.

\section{Acknowledgements}

We would like sincerely to thank Pat Simms and the Loyola University FACS Core Facility for their invaluable assistance with flow cytometric methods, and Elizabeth A Durbin, MS, and Christine V Fontanilla, MS for their generous assistance with animal procedures and sample collection. We are grateful to Nancy Lapaglia for assistance with the testosterone RIA. This work was supported by NIH GM55344, AG16067.

\section{References}

Angele MK, Wichmann MW, Ayala A, Cioffi WG \& Chaudry IH 1997 Testosterone receptor blockade after hemorrhage in males. Restoration of the depressed immune functions and improved survival following subsequent sepsis. Archives of Surgery 132 1207-1214

Angele MK, Ayala A, Cioffi WG, Bland KI \& Chaudry IH 1998 Testosterone: the culprit for producing splenocyte immune depression after trauma hemorrhage. American Journal of Physiolology 274 C1530-C1536.

Benten WP, Lieberherr M, Giese G, Wrehlke C, Stamm O, Sekeris CE, Mossmann H \& Wunderlich F 1999 Functional testosterone receptors in plasma membranes of T cells. FASEB Journal 13 123-133.

Bodker A, Andersson KE, Batra S, Juhl BR \& Meyhoff HH 1994 The estrogen receptor expression in the male rabbit urethra and prostate following castration. Scandinavian Journal of Urology and Nephrology 28 113-118.

Chertin B, Spitz IM, Lindenberg T, Algur N, Zer T, Kuzma P, Young AJ, Catane R \& Farkas A 2000 An implant releasing the gonadotropin hormone-releasing hormone agonist histrelin maintains medical castration for up to 30 months in metastatic prostate cancer. Journal of Urology 163 838-844.

Christeff N, Carli A, Benassayag C, Bleichner G, Vaxelaire JF \& Nunez EA 1992 Relationship between changes in serum estrone levels and outcome in human males with septic shock. Circulatory Shock 36 249-255.

Dinkel RH \& Lebok U 1994 A survey of nosocomial infections and their influence on hospital mortality rates. Journal of Hospital Infection 28 297-304.

Falsetti L, Gambera A, Legrenzi L, Iacobello C \& Bugari G 1999 Comparison of finasteride versus flutamide in the treatment of hirsutism. European Journal of Endocrinology 141 361-367.

Faunce DE, Gregory MS \& Kovacs EJ 1997 Effects of acute ethanol exposure on cellular immune responses in a murine model of thermal injury. Journal of Leukocyte Biology 62 733-740.

Fourrier F, Jallot A, Leclerc L, Jourdain M, Racadot A, Chagnon JL, Rime A \& Chopin C 1994 Sex steroid hormones in circulatory shock, sepsis syndrome, and septic shock. Circulatory Shock 43 171-178.

Fukushima R, Alexander JW, Wu JZ, Mao JX, Szczur K, Stephens AM, Ogle JD \& Ogle CK 1994 Time course of production of cytokines and prostaglandin E2 by macrophages isolated after thermal injury and bacterial translocation. Circulatory Shock 42 154-162.

Gregory MS, Duffner LA, Faunce DE \& Kovacs EJ 2000a Estrogen mediates the sex difference in post-burn immunosuppression. Journal of Endocrinology 164 129-138. 
Gregory MS, Faunce DE, Duffner LA \& Kovacs EJ $2000 b$ Gender difference in cell-mediated immunity after thermal injury is mediated, in part, by elevated levels of interleukin-6. Journal of Lenkocyte Biology 67 319-326.

Gregory MS, Faunce DE \& Kovacs EJ 2000c Differential production of prostaglandin E2 in male and female mice subjected to thermal injury contributes to the gender difference in immune function: possible role for 15-hydroxy-prostaglandin dehydrogenase. Cell Immunology 205 94-102.

Hansbrough J, Peterson V, Zapata-Sirvent R \& Claman HN 1984 Postburn immunosuppression in an animal model. II. Restoration of cell-mediated immunity by immunomodulating drugs. Surgery 95 290-296.

Horgan AF, Mendez MV, O'Riordain DS, Holzheimer RG, Mannick JA \& Rodrick ML 1994a Altered gene transcription after burn injury results in depressed T-lymphocyte activation. Annals of Surgery 220 342-351.

Horgan AF, O'Riordain DS, Chin DH, Mannick JA \& Rodrick ML $1994 b$ The role of cyclic adenosine monophosphate in the suppression of cellular immunity after thermal injury. Archives of Surgery 129 1284-1289.

Kemppainen JA, Lane MV, Sar M \& Wilson EM 1992 Androgen receptor phosphorylation, turnover, nuclear transport, and transcriptional activation. Specificity for steroids and antihormones. Journal of Biological Chemistry 267 968-974.

Knoferl MW, Diodato MD, Angele MK, Ayala A, Cioffi WG, Bland KI \& Chaudry IH 2000 Do female sex steroids adversely or beneficially affect the depressed immune responses in males after trauma-hemorrhage? Archives of Surgery 135 425-433.

Krause DS \& Deutsch C 1991 Cyclic AMP directly inhibits IL-2 receptor expression in human $\mathrm{T}$ cells: expression of both p55 and p75 subunits is affected. Journal of Immunology 146 2285-2296.

Kruithof-Dekker IG, Tetu B, Janssen PJ \& Van der Kwast TH 1996 Elevated estrogen receptor expression in human prostatic stromal cells by androgen ablation therapy. Journal of Urology 156 1194-1197.

Kupper TS, Baker CC, Ferguson TA \& Green DR 1985 A burn induced Ly-2 suppressor T cell lowers resistance to bacterial infection. Journal of Surgical Research 38 606-612.

Lephart ED, Baxter CR \& Parker CR Jr 1987 Effect of burn trauma on adrenal and testicular steroid hormone production. Journal of Clinical Endocrinology and Metabolism 64 842-848.

Meert KL, Ofenstein JP, Genyea C, Sarnaik AP \& Kaplan J 1996 Elevated transforming growth factor-beta concentration correlates with posttrauma immunosuppression. Journal of Trauma 40 901-906.

Miller-Graziano CL, Szabo G, Griffey K, Mehta B, Kodys K \& Catalano D 1991 Role of elevated monocyte transforming growth factor beta (TGF beta) production in posttrauma immunosuppression. Journal of Clinical Immunology 11 95-102.

Miller-Graziano CL, Szabo G, Kodys K \& Mehta B 1993 Interactions of immunopathological mediators (tumor necrosis factor-alpha, TGF-beta, prostaglandin E2) in traumatized individuals. In Host Defense Dysfunction in Trauma, Shock and Sepsis; Mechanisms and Therapentic Approaches, pp 637-650. Eds EMJ Faist \& FW Schildberg. New York: Springer-Verlag.

Moss NM, Gough DB, Jordan AL, Grbic JT, Wood JJ, Rodrick ML \& Mannick JA 1988 Temporal correlation of impaired immune response after thermal injury with susceptibility to infection in a murine model. Surgery 104 882-887.

Offner PJ, Moore EE \& Biffl WL 1999 Male gender is a risk factor for major infections after surgery. Archives of Surgery 134 935-938.

Olsen NJ \& Kovacs WJ 1996 Gonadal steroids and immunity. Endocrine Reviews 17 369-384.

Olsen NJ, Viselli SM, Shults K, Stelzer G \& Kovacs WJ 1994 Induction of immature thymocyte proliferation after castration of normal male mice. Endocrinology 134 107-113.
O’Mahony JB, Wood JJ, Rodrick ML \& Mannick JA 1985 Changes in $\mathrm{T}$ lymphocyte subsets following injury. Assessment by flow cytometry and relationship to sepsis. Annals of Surgery 202 580-586.

O'Riordain DS, Mendez MV, O'Riordain MG, Molloy RG, Holzheimer RG, Collins K, Saporoschetz I, Mannick JA \& Rodrick ML 1993 Molecular mechanisms of decreased interleukin-2 production after thermal injury. Surgery 114 407-414.

O'Riordain DS, Mendez MV, Holzheimer RG, Collins K, Mannick JA \& Rodrick ML 1995 Interleukin-2 receptor expression and function following thermal injury. Archives of Surgery 130 165-170.

Samy TS, Schwacha MG, Cioffi WG, Bland KI \& Chaudry IH 2000 Androgen and estrogen receptors in splenic T lymphocytes: effects of flutamide and trauma-hemorrhage. Shock 14 465-470.

Schroder J, Kahlke V, Staubach K-H, Zabel P \& Stuber F 1998 Gender differences in human sepsis. Archives of Surgery 133 $1200-1205$.

Sharma AC, Bosmann HB, Motew SJ, Hales KH, Hales DB \& Ferguson JL 1996 Steroid hormone alterations following induction of chronic intraperitoneal sepsis in male rats. Shock 6 150-154.

Smith GS \& Kraus JF 1988 Alcohol and residential, recreational, and occupational injuries. Annual Review of Public Health 999-121.

Sparkes BG 1993 Mechanisms of immune failure in burn injury. Vaccine 11 504-510.

Tchervenkov JI, Epstein MD, Silberstein EB \& Alexander JW 1988 Early burn wound excision and skin grafting postburn trauma restores in vivo neutrophil delivery to inflammatory lesions. Archives of Surgery 123 1477-1481.

Teodorczyk-Injeyan JA, Sparkes BG, Mills GB, Peters WJ \& Falk RE 1986 Impairment of T cell activation in burn patients: a possible mechanism of thermal injury-induced immunosuppression. Clinical and Experimental Immunology 65 570-581.

Teodorczyk-Injeyan JA, Sparkes BG, Peters WJ, Gerry K \& Falk RE 1987 Prostaglandin E-related impaired expression of interleukin-2 receptor in the burn patient. Advances in Prostaglandin, Thromboxane and Leukotriene Research 17A 147-150.

Teodorczyk-Injeyan JA, Sparkes BG \& Peters WJ 1989 Serum interleukin-2 receptor as a possible mediator of immunosuppression after burn injury. Journal of Burn Care and Rehabilitation 10 112-118.

Viselli SM, Reese KR, Fan J, Kovacs WJ \& Olsen NJ 1997 Androgens alter B cell development in normal male mice. Cell Immunology 182 99-104.

Waldman TA 1986 The structure, function and expression of interleukin-2 receptors on normal and malignant lymphocytes. Science 232 727-732.

Weinstein Y \& Berkovich Z 1981 Testosterone effect on bone marrow, thymus, and suppressor T cells in the (NZB X NZW)F1 mice: its relevance to autoimmunity. Journal of Immunology 126 998-1002.

West N, Chang C, Liao S \& Brenner R 1990 Localization and regulation of estrogen, progestin and androgen receptors in the seminal vesicle of the rhesus monkey. Journal of Steroid Biochemistry and Molecular Biology 37 11-21.

Wichmann MW, Zellweger R, DeMaso CM, Ayala A \& Chaudry IH 1996 Mechanism of immunosuppression in males following traumahemorrhage. Critical role of testosterone. Archives of Surgery 131 1186-1191.

Wichmann MW, Angele MK, Ayala A, Cioffi WG \& Chaudry IH 1997 Flutamide: a novel agent for restoring the depressed cellmediated immunity following soft-tissue trauma and hemorrhagic shock. Shock 8 242-248.

Wolfe JH, Wu AV, O'Connor NE, Saporoschetz I \& Mannick JA 1982 Anergy, immunosuppressive serum, and impaired lymphocyte blastogenesis in burn patients. Archives of Surgery 117 1266-1271.

Wood JJ, Rodrick ML, O'Mahony JB, Palder SB, Saporoschetz I, D'Eon P \& Mannick JA 1984 Inadequate interleukin 2 production. A fundamental immunological deficiency in patients with major burns. Annals of Surgery 200 311-320. 
Woolf PD, Hamill RW, McDonald JV, Lee LA \& Kelly M 1985 Transient hypogonadotropic hypogonadism caused by critical illness. Journal of Clinical Endocrinology and Metabolism 60 444-450.

Zaccheo T, Giudici D \& di Salle E 1999 Combined treatment with the 5 alpha-reductase inhibitor PNU 157706 and the antiandrogen flutamide on the Dunning R3327 prostatic carcinoma in rats. Endocrine-Related Cancer 6 429-435.

Received in final form 28 December 2000 Accepted 19 January 2001 